\title{
E-GOVERNMENT AS A METHOD FOR LEGAL COMMUNICATION BETWEEN CIVIL SOCIETY AND PUBLIC ADMINISTRATION
}

Olena Makeieva $\mathrm{PhD}$ in Law, Associate Professor of the Department of Theory and History of State and Law, National Aviation University 1 Liubomyr Huzar Ave., Kyiv, Ukraine, 03058 https://orcid.org/0000-0001-6101-2951 maklena72@ukr.net

Liudmyla Shapenko PhD in Law, Associate Professor of the Department of Theory and History of State and Law, National Aviation University 1 Liubomyr Huzar Ave., Kyiv, Ukraine, 03058 https://orcid.org/0000-0001-7351-641X shapenkol@ukr.net

Kateryna Vodolaskova PhD in Law, Associate Professor of the Department of Theory and History of State and Law, National Aviation University 1 Liubomyr Huzar Ave., Kyiv, Ukraine, 03058 https://orcid.org/0000-0002-6133-822X khusanova@gmail.com

\begin{abstract}
E-government is a form of public administration which promotes efficiency, openness and transparency of public authorities and local governments with the use of information and telecommunications technologies to form a new type of state focused on meeting the needs of citizens. E-government is studied as a way, a form, the concept, system and mechanism of cooperation between the state (public administration) and public sectors (civil society). As a method for legal communication between civil society and public administration, e-government plays the role of a means of public self-government, which involves interactivity and continuity of interaction between citizens and the state, the presence of public control over the activities of public authorities. This article is dedicated to reveal the role of e-government for realizing the goals of legal communication between its participants in public life. However, further in-depth analysis requires understanding the role of e-government as a means of legal communication, changing the focus and direction of its development in the digital age, as well as exploring promising areas of legal regulation of virtual legal relations between public authorities and civil society. The implementation of e-government in Ukraine should be provided on a qualitatively new level to develop
\end{abstract}


efficient legal communication between government and society as a whole, strengthen confidence in the state and its policies, improve cooperation between public authorities and local governments, business, citizens and civil servants. The authors of this article adhered to its purpose, which is to analyze the understanding of the role of e-government as a means of legal communication, changing the focus and direction of its development in the digital age, and exploring promising areas of legal regulation of virtual legal relations between government and civil society.

Keywords: legal communication, e-governance, digital society.

\section{INTRODUCTION}

The development of e-government is one of the main factors in ensuring the success of reform and increasing the country's competitiveness. The reform of any industry in modern conditions is aimed at the widespread use of modern information and communication technologies to achieve the required level of efficiency and effectiveness. After all, it is the tools of e-government that can significantly improve the quality of service for individuals and legal entities and increase the openness, transparency and efficiency of public administration.

In the framework of the Association Agreement between Ukraine, on the one hand, and the European Union, the European Atomic Energy Community and their Member States, on the other hand, Ukraine must ensure the integrated development of e-government in accordance with European requirements.

The introduction of e-government is also a basic prerequisite for building an efficient digital economy and digital market in Ukraine and its further integration into the EU digital single market (Digital Single Market Strategy for Europe).

Moreover, the development of e-government and democratic processes, the application of a universally recognized system of democratic values, in particular the participation of citizens and civil society institutions in the formation and implementation of public policy play a key role in ensuring economic and social progress.

E-government or governance with the widespread use of various information technologies since its inception has been aimed at improving the efficiency of government with citizens, businesses and other administrations, i.e. to reduce the total cost of time and money.

However, the Conference of e-Leaders of the Organization for Economic Co-operation and Development (OECD) discussed the need to change the focus and direction of e-government: increase the efficiency and effectiveness of administrations by posting e-government services on the Internet.

In Ukraine, e-government is still in its basic stage of development, which makes it important to study effective methods and forms of public administration and public policy in the information society.

Analysis of the use of e-government in Ukraine shows its fragmentary nature, duplication of work and inconsistency of regulations. E-governance is not a mechanical combination of 
new information technologies and existing outdated administration. This is a new philosophy of public administration, for its implementation it is necessary to develop a fundamentally new legal framework and adapt it to the relevant international documents, especially the $\mathrm{EU}$, and to the peculiarities of the use of information technology itself.

E-government is a complex process and is a practical tool for realizing the goals of legal communication between its participants in public life.

In the scientific legal literature, the problem of legal communication remains insufficiently studied. Issues of legal communication have been studied by both domestic and foreign scholars. In particular, J. Habermas studied the communicative act, G. Peters studied the history of communication, Mark van Hook considered law as communication, A. Polyakov is a representative of the communicative approach to law, A. Tokarska studied legal communication in the context of non-classical legal understanding, I. Chestnov analyzed the dialogic interaction in law. Various aspects of legal communication were studied by V. Bachinin, N. Luman, S. Maksimov, N. Onishchenko, P. Rabinovych and others. Scientific analysis of the works of famous scientists gives grounds to state the lack of unity in approaches to understanding the nature, concept and essence of legal communication.

However, further in-depth analysis requires understanding the role of e-government as a means of legal communication, changing the focus and direction of its development in the digital age, as well as exploring promising areas of legal regulation of virtual legal relations between public authorities and civil society.

\section{MATERIALS AND METHODS}

The methodological basis of the study consists of a system of philosophical, general scientific and special scientific methods. The work is based on a comprehensive approach for the analysis of legal communication, as well as a general scientific method of dialectics. The combination of general epistemological methods of analysis and synthesis, abstract and concrete in the knowledge of state and legal phenomena, induction and deduction allowed to realize the requirements of objectivity, completeness, integrity, validity and systematic research. System-activity approach in clarifying the role of legal communication in the process of law enforcement and law-making activities.

Moreover, statistical approach was used to study the level of e-government readiness by country and cyber offences counteraction.

\section{RESULTS AND DISCUSSION}

A. Tokarska highlights the joint solution of issues by means of legal communication. Tackling of problematic relations lies in the plane of legal communication, which is the source of formation and object of application of law. The law cannot be the unappealable will of the legislative public administration or the will of another state; it can be developed as an ontological result of intersubjective interaction (Tokarska, 2016). 
In the era of rapid development of information and communication technologies, legal relations are characterized by large-scale processes of digitalization. The study of the problems of legal communication requires a new approach to modern jurisprudence on the basis of existing developments in the theory of state and law, philosophy of law, sociology of law, linguistics and other sciences. Legal communication is the basic purpose of interaction of subjects of law for balancing of positions, the decision of problem situations. In fact, legal communication is relevant where and when there is a conflict, a mismatch of positions, different views on solving the problem situation.

Legal communication arises and develops in the process of society development. Its origins date back to the era of the ancient world. The first oral and written communicative acts have the character of religious norms that expressed the motives of human behavior. The theory of communication was studied by Plato, Aristotle, Cicero, M. Aurelius, and A. Augustine, who initiated the theoretical elaboration of the idea of social dialogue (Kononenko, 1994).

Regarding the understanding of the original function of communication as an effective tool for regulating social relations, the views of researchers coincide (V. Kravitz, L. Ozadovska, 0. Petroe, A. Polyakov, A. Tokarska, I. Chestnov, etc.).

According to 0 . Petroye's opinion the first concept of social dialogue is the idea of solidarity, which marks a set of different aspects of unity - interests, beliefs, values, actions in relations between people who share common values and form a certain social integrity (Petroye, 2012).

A Polyakov, a representative of the communicative theory of law, believes law is a form of normalized psycholinguistic activity of subjects (physical and legal) in the context of communicative intersubjective interaction, the consequences of which are objectified in legal culture, social institutions, legal texts and affect legal awareness, legal norms and legal relations that form a single legal structure (Polyakov, 2002).

According to Mark van Hook, law is always essentially based on communication: communication between the legislator and citizens, between the legislator and the judiciary, communication between the parties to the contract, communication in court. This communicative aspect is considered today in the framework of the legitimation of law: a rational dialogue between lawyers as the main guarantee for the „correct” interpretation and application of law (van Hook, 2012).

The diversity of assessments of legal communication allows us to declare legal communication is:

1. the process of exchange and interaction (interaction) of legal information used by various state and legal institutions in management activities of organizational, economic, social and other nature;

2. the process of realization of legal communication is carried out by social institutions that create and transmit legal information in time and space; 3) interpersonal legal communication in the process of communicative-legal relations (Provencher, 2013).

Thus, legal communication is a set of processes and entities that ensure the purposeful circulation and dissemination of legal information and legal knowledge in the modern information space. 
During legal communication, intersubjective legal relations arise, which are the source of the rights and obligations of the subjects. The rules of law enshrine the rights and obligations of the subjects, on the basis of which they enter into communication both with each other and with the state. The ability to enter into legal communications is inherent in the subjects of public relations - citizens, their associations, public (public) authorities etc.

Objective factors influencing legal communication include the following: the state of law and order, the appropriate level of legal protection and social adaptation in society, the effectiveness of legal norms, flexibility and harmony of the legal system, timely response to changes in society. Legal communication affects the development of Ukrainian society in the context of European integration.

Over the past two years, Ukraine has been experiencing a concentrated impact of challenges of various kinds: from internal socio-political problems to external information and military aggression. Communication becomes an integral part of the national security system when there is a consistent effort to destabilize the situation in the country, which ultimately aims to undermine public confidence in the government, and thus dismantle the existing system of government (Yablonsky, 2016).

An important aspect of the impact of law on the state is its communicative nature. In particular, the ability of the legal norm to enshrine the rights and obligations of the subjects, on the basis of which they enter into communication both with each other and directly with the state. The opportunity to enter into legal communications is inherent for every subject of public relations without exception: for people, their associations, public administration etc. (Kozyubra, 2015).

The development of information and communication technologies contributes to changes in public relations, which in turn have an impact on the institution of interaction between the state and citizens. The state must provide civil society with legal information, provide comments on regulations, which increases the level of their legal knowledge and, consequently, legal culture.

The essence of communicative interaction between the state and civil society is not just a dialogical act, where the experience of cooperation is formed, which in the future will be the basis for the development of a high level of legal culture to ensure the rule of law in society. This is expressed in the following:

- communicative interaction: the basis of interaction - the legal awareness of the subjects of law, formed in the process of legal relations, the action of law and the legal system;

- the principle of justice, which is an integral part of professional activity in the field of law;

- the lawful conduct of the subject of law: freedom and morality.

The most difficult expression of the nature of communicative activity is the manifestation of the degree of freedom in combination with the degree of responsibility of the subjects of communication, freedom, and the requirements of morality.

Legal communication is the main purpose of interaction of subjects of law for realization of the rights and freedoms, the decision of legal conflicts. In fact, legal communication is actualized when there is a conflict, a mismatch of positions, different views on the solution of the legal situation. The conflicting nature of the relationship between the subjects of law 
is transmitted as an inevitable sign of social existence. Therefore, its study is perhaps the most difficult feature of research in legal communication. As a rule, the manipulation of conflict communication is usually hidden behind the substitution of subjective and objective intentions to prove their «legality» of each social phenomenon, the boundaries of which are «vague and clearly not visible» due to the variety of causes and phenomena. Analysis of legal communication in the plane of conflict proves that interaction is not always simple, and informative communication (communication) is partly fundamentally complicated for the sake of one thing: the achievement of each side of its goal.

Based on the principles of democracy, the goal of the state is not to submit to a single government, but to create a system of legal communication and legal communication aimed at reconciling the will of citizens who participate in them, forming legal ties that ensure the realization of their legal interests. Law as a subject-communicative system is characterized by a special way of communication (Horbenko, 2017).

\section{DISCUSSIONS}

What makes civil society important and strong in any context is not its existence as an entity but rather the quality and number of relationships between citizens and state actors that are mediated by a variety of institutions and organizations, including sometimes branches of the state itself (Uphoff; Krishna, 2004). Hence, e-government is an effective way and form for cooperation between civil society institutions (CSI) as well as between public administration and CSI.

In Ukraine, the sphere of legal communication «government-public» is regulated by information legislation, which at the time of its adoption met key democratic standards, but currently it is not able to meet the needs of society. The authorities are still obliged to «inform" and «cover» their activities, and not to make decisions in the process of dialogue with the public. Despite the fact that de facto relevant legislation (openness, transparency of public authorities and local governments, citizen participation in the development and implementation of public policy) are quite developed, their implementation is of inadequate quality. It should be noted that in the last decade the study of legal communication is necessary because it is used in almost all areas of public relations that require legal regulation. This is facilitated by the implementation of technologies of e-government, e-justice, e-democracy, e-parliamentarismand e-parliament, the need to combat cybercrime and cyberterrorism, regulation of the Internet. The modernization of law requires the conscious support of citizens who will provide ICT in the process of new forms of interaction between government and society in accordance with the principles of deliberative democracy. A large set of theoretical and practical problems has recently been developed autonomously in this regard within the concept of electronic rule-making (e-rule development). It is significant that with the support of the world's leading law schools - Yale, Harvard, New York and other theories, methodologies and technologies have found support and dissemination not only in the United States but also in the world's leading countries (Noveck, 2011).

The need for state influence, the formation of a separate state policy in the field of information society and the creation of favorable conditions for the development of 
e-government is defined as a way of legal communication, especially in the Tunisian (2005) and Geneva (2003) World Summits development of the information society, in the Okinawan Charter for the Development of the Global Information Society (von Braun, 2001).

The very concept of «e-government» was introduced into political and scientific circulation by specialized research organizations that deal with a wide range of issues related to the functioning of the state, in particular, international organizations such as the UN, World Bank, International Union of Electricity language. Currently, this concept is multifaceted and multidimensional, due to the emphasis on various aspects and principles of implementation and functioning of e-government. A separate issue is the problem of understanding e-government in different countries, which is associated with different levels of education in the country, its ICT potential, traditions of public administration, the level of socio-political consciousness of the population and so on.

With the advent and development of information and communication technologies, the approach to public administration has changed, new concepts and concepts have emerged, including e-government and e-governance. They are used both to characterize the processes of public administration and the formation of civil society.

The ancestor of these concepts and concepts was the United States. Their main content can be understood from the US Strategy, which emphasizes that "the President's vision of a new administrative reform emphasizes the need to change the operational component of the government in terms of its own functioning and interaction with the citizens it serves. The basis of this change are three principles:

- government should focus on the citizens, not on the bureaucracy;

- government should focus on the results of its activities;

- government should be based on the market, actively promoting innovations(Office of Management and Budget, 2002).

Nowadays e-government and e-governance have become global phenomena: governments of developed countries use these concepts to promote citizen participation in public life and empower them. Despite the single semantic orientation of the concepts, they nevertheless differ in their content. Thus, the common denominator for e-government and e-governance is that both e-government and e-governance provide for the automation or computerization of existing paper procedures, which will prompt new leadership styles, new ways of discussing and making strategic decisions, new ways conducting business, new ways of conveying the views of citizens and communities, as well as new ways of organizing and providing information.

The authors of this study believe that e-government should be considered in a broader functional sense, namely: as a way of effective, constructive and targeted legal communication between civil society and public administration.

E-governance provides the public with ample opportunities to participate in the political life of society and is expressed in the interaction of government, citizens and non-governmental public institutions based on the widespread use of ICT (The European eGoverment Action Plan 2011-2015).

The cornerstone of the reform of government-citizen relations is the Draft Principles of Government Information Strategies: Convergence of Government with Citizens and Business, 
prepared by the OECD in October 2013 (Draft OECD Principles on Digital Government Strategies, 2013). In essence, it is a roadmap that describes how digital opportunities can enhance the importance of the public and reduce the risks associated with the quality of public services, public sector efficiency, social integration and citizen participation, public trust, and multilevel and multi-actor management.

Effective use of ICT to serve citizens on the Internet is a challenge and a challenge for many governments, especially in developing countries. Government organizations face high levels of uncertainty in the design and delivery of e-government services due to the complexity of technology, deep-rooted organizational routines, and the great diversity in people's acceptance of technology. E-government requires much more than technical skills to develop and operate successful Internet services. This includes developing strategic approaches to organizing and collecting tangible resources, such as computers and networks, and intangible resources, such as employee skills and knowledge and organizational processes. Therefore, government organizations must consider two factors in order to succeed. These include: the presence of a significant number of citizens who are willing and able to accept and use Internet services; and, developing the managerial and technical capacity to implement e-government programs to meet the needs of citizens (Prattipati 2003).

These two factors are measured as a country's readiness for e-government. Map 1 shows the level of e-government readiness by country. Obviously, some organizations are better at building e-government systems than others to meet these requirements. Most developing countries have a lower level of readiness to provide e-government services than developed countries. Developing country governments face similar limitations in building e-government. These restrictions sharply shape the mismatch between the level of acceptance and use of e-government in developed economies.

Map 1 - E-Government Readiness by Country in 2007

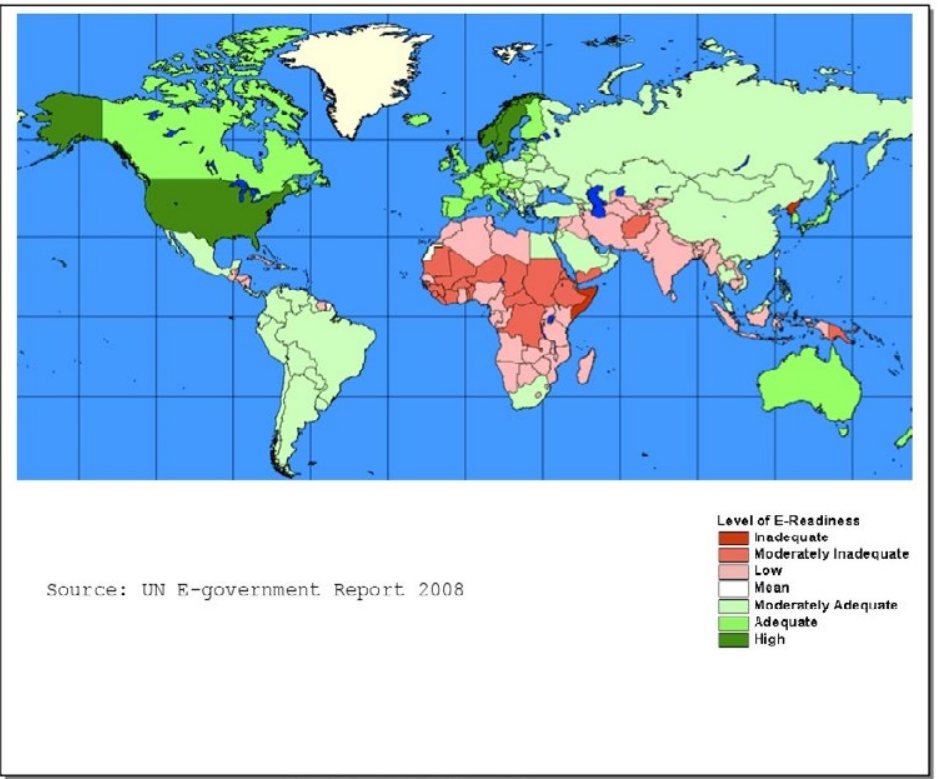

Map 1 
The United Nations Department of Economic and Social Affairs (UN DESA) conducts a survey of the UN e-government and prepares for two years according to the established methodology. The department is looking at how digital government can promote integrated policies and services in 193 UN member states. The survey supports countries' efforts to provide effective, accountable and comprehensive digital services to all and bridge the digital divide and leaves no one behind.

Such an e-government survey is a key ranking, mapping and measurement tool that supports the digital transformation of countries.

According to a survey conducted in 2020, the situation with the introduction of e-government in the world has changed significantly in 10 years. Map 2 shows the state of development of e-government in the world as of 2020.

In 2020, there were transformational changes in global development during the unprecedented COVID-19 pandemic. While the pandemic has revived the role of e-government in both traditional digital services and new innovative crisis management efforts, it has also highlighted the challenges and various forms of digital divide, especially among the poorest and most vulnerable groups.

The ranking of 193 UN member states on the level of digital government by 2020, taking into account the volume and quality of online services, the state of telecommunications infrastructure and existing human potential, is led by Denmark, the Republic of Korea and Estonia, followed by Finland, Australia, Sweden, Great Britain, Nova Zealand, the United States, the Netherlands, Singapore, Iceland, Norway and Japan.

Among the least developed countries, Bhutan, Bangladesh and Cambodia have become leaders in the development of digital government, moving from the middle to the highest group of the e-government development index (EGDI) in 2020. Mauritius, Seychelles and South Africa lead the government ranking in Africa. Overall, 65 percent of Member States are at a high or very high level of EGDI (2020 United Nations E-Government Survey, 2020).

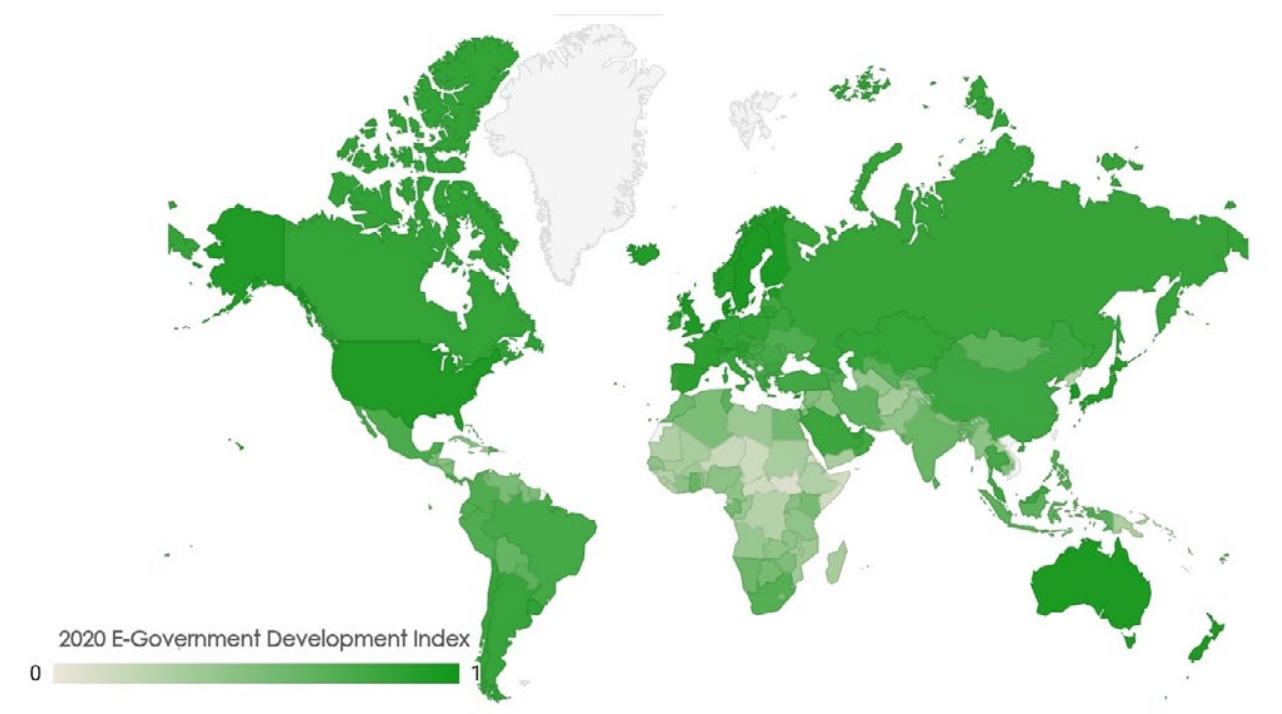

Map 2

Researching international e-government standards should emphasize their recommendatory nature for signatory states that stand in the way of implementing IT technologies in all spheres of life. 
However, there are a number of international e-government standards that are clearly enshrined in international instruments on the formation of the information society and are mandatory. In addition to these international documents, these include:

1. The Recommendation of the Committee of Ministers to member states on electronic democracy (e-democracy) (Recommendation CM/Rec (2009);

2. Directive 1999/93/EC of the European Parliament and of the Council of 13 December 1999 on a Community framework for electronic signatures (Directive 1999/93/EC);

3. UNCITRAL Model Law on Electronic Signatures (2001);

4. Declaration of the Committee of Ministers on human rights and the rule of law in the Information Society (1999) etc.

The Recommendation of the Committee of Ministers of the Council of Europe on e-Government (2004), in particular, sets out the following steps for the development of e-government in the signatory states:

1. Review the policy of implementation of e-government technologies, legislation and practice of its application in this area.

2. Involve relevant foreign and national experts in order to create a joint strategy for the implementation and development of e-government.

3. Develop an e-government strategy that: fully complies with the principles of the national organization of democratic governance; will contribute to the positive development of democratic processes, etc (Recommendation CM/Rec (2009).

Approaching international, in particular, European values is the most pressing issue for Ukrainian society for a long time. This desire requires certain changes from the domestic legal system, which are ideally aimed at raising the standard of public life within the country and improving its position in the international arena. National legal bases are being reformed by adapting them to international and European standards. However, in practice there are certain shortcomings of such implementation, which are most noticeable in the areas of public law, where the state has a wide range of powers.

According to the level of e-government development, Ukraine ranks 69th among 193 UN member states, the e-government development index is 0.7119 (the average index is 0.6). Of course, compared to the data for 2018, when Ukraine ranked 75th in the world, this development has a positive trend, but Ukraine still needs to implement a number of standards and measures to implement the concept of e-government (2020 United Nations E-Government Survey (2020).

In the EU Strategy and Program for the Development of the Information Society, as well as in the Law of Ukraine «On the National Digitalization Program». According to this and other documents, the state has the main organizing, coordinating and controlling role in the relations arising in the process of building the information society and implementing e-government between its main actors: the state, business, international and public organizations: "Creating an open for all, the information society needs new forms of partnership and cooperation between public administration and the private sector, civil society and international organizations.... at the same time, public administration bodies have a leading role in the development and implementation of promising and well- 
established national e-strategies (On the National Digitalization Program. Law of Ukraine, 1998).

The Ukrainian government has approved the Concept for the Development of e-Government in Ukraine. The document defines the directions, mechanisms and terms of formation of an effective e-government system in Ukraine to meet the interests and needs of individuals and legal entities, improve public administration, increase competitiveness and stimulate socioeconomic development of the state. Implementation of the Concept will allow: to increase the efficiency of public authorities and local governments and achieve a qualitatively new level of government based on the principles of efficiency, effectiveness, transparency, openness, accessibility, trust and accountability; to improve the quality of public services to individuals and legal entities in accordance with European requirements, as well as to ensure the necessary mobility and competitiveness of citizens and businesses in modern economic conditions; minimize corruption risks in the exercise of power; to improve the investment attractiveness, business climate and competitiveness of the country; to stimulate socio-economic development in Ukraine (On approval of the Concept of e-government development in Ukraine, 2017).

However, a number of problems arise in the implementation of this Concept. One of the problems with the introduction of e-government in Ukraine is the lack of a clear hierarchy of interrelated documents from the Constitution of Ukraine, which defines the basic principles of state information policy, to a document that defines, for example, interdepartmental information exchange or circulation. The existing experience in implementing the National Digitalization Program, which currently underlies these processes, has shown its inefficiency, including due to the imperfection of institutional policy.

In Ukraine, e-government is still in its infancy, which makes it important to study the methods and forms of public administration and public policy in the information society.

The analysis of the application of e-government in Ukraine shows its fragmentary nature, duplication of work and inconsistency of regulations. E governance is not a mechanical combination of new information technologies and existing outdated administration. This is a new philosophy of public administration, for its implementation it is necessary to develop a fundamentally new legal framework and adapt it to the relevant international documents, especially the EU, and to the peculiarities of the use of information technology itself.

The state policy of development of information society and e-government as a means of legal communication should be based, first of all, on the principles of cooperation and partnership, which provides control of state actions by society and business, excludes application of command-administrative models and directive mechanisms. other subjects of the process and among themselves. Thus, the International initiative "Partnership «Open Government» (2011), which Ukraine joined in 2011, provides for the formation of a new type of public sector organization.

In addition to the above principles of cooperation and partnership, public policy for the implementation of e-government must be based on a system of principles such as:

- transparency and openness of government;

- confidentiality and information security;

- common technical standards and mutual compatibility; 
- focus on the interests and needs of service consumers;

- control and accountability of the authorities to citizens and society.

Along with new developments and advances in the IT field, there is a need to create reliable protection of cyberspace. To reduce the risk of threats, considerable attention should be paid to cybersecurity.

One of the reasons for the spread of cybercrime is not a technical malfunction or ignorance of programmers, but certain gaps in the law and the lack of uniform rules to be applied in the event of a cyber-attack. In 2016, the Decree of the President of Ukraine approved the Cyber Security Strategy of Ukraine, which aimed to create conditions for the safe operation of cyberspace, its use in the interests of the individual, society and the state. Immediately a year later, in 2017, the Law of Ukraine „On the Basic Principles of Cyber Security of Ukraine" was adopted. It is considered the first normative document concerning the sphere of cybersecurity. However, this piece of legislation does not contain specific practical rules for application if necessary, it sets out more general provisions and describes the main aspects of this area. The Law of Ukraine «On Basic Principles of Cyber Security of Ukraine" defines the main activities and principles of state policy in the field of cybersecurity, the powers of state bodies, enterprises, institutions, organizations, individuals and citizens in this area, the basic principles of coordinating their cybersecurity activities. The law aims to protect both the citizen and the state as a whole(On Basic Principles of Cyber Security of Ukraine (2017).

The United States is a clear example for Ukraine in the development of cybersecurity. The American experience today is taking over the world, as they have developed effective security standards (NIST Cybersecurity Framework) that actually help detect, respond to, and even prevent cyberattacks. Back in 2016, the United States developed the Cybersecurity National Security Action Plan. In addition, they have criminal law in the field of cybercrime, a number of laws governing cybersecurity issues and policy documents adopted at the state level, including strategies for cyberspace and cybersecurity action plans. Each state also adopts its own regulations to ensure an adequate level of cyberspace protection.

As for the EU countries, they also pay considerable attention to this issue and can serve as an example to follow. The main document that deserves attention and the possibility of its implementation in the regulatory framework of our state is the Directive on Network and Information Security («NIS Directive»). This document sets out the general approach and EU rules in the field of cybersecurity. It aims to step up cybersecurity cooperation between EU countries, as the first thing cybercriminals encroach on is confidential data. This Regulation also refers to the legal standard of cybersecurity, because in case of compliance with the requirements, the level of protection of personal information in the digital environment is significantly increased (Horbenko, 2018).

In 2020 specialists of the National Coordination Center for Cyber Security at the National Security and Defense Council began developing a Cyber Security Strategy of Ukraine, which will determine the priorities of Ukraine's national interests in cyber security and the main approaches and directions to cyber security. The new Strategy is promised to take into account international best practices for its effective implementation (The National Security and Defense Council, 2020). 
Given the above, we can conclude that certain steps have been taken to develop cybersecurity in Ukraine and a big plus in this is US assistance. Of course, it is necessary to improve the national legislation governing information security, to develop possible new programs, plans, and, in addition, it is necessary to implement the adopted norms in practice, using the experience of leading countries.

\section{CONCLUSIONS}

Legal communication contributes to the formation of legal values in the modern information space, a positive perception of law, improving the legal policy of the state and state information policy. The conditions of Ukraine's origin in the world information space are: improvement of the legal mechanism of interaction between government and society, solving the problem of ensuring effective development of national information infrastructure, creation of information analytical system of public authorities, acceleration of modernization of material and technical base, reliable protection of information resources. An effective means of implementing legal communication is the introduction of e-government. The development of the information society and one of its key components e-government, is a modern global trend that leads to significant changes in public relations and the economy.

The implementation of e-government in Ukraine should provide a qualitatively new level of government and society as a whole, strengthen confidence in the state and its policies, improve cooperation between public authorities and local governments, business, citizens and civil servants.

A well-built e-government system should have a positive impact on the overall course and consequences of further radical transformations in Ukrainian society, first of all, social and economic reform, building a welfare state with influential civil society institutions, especially on issues where methods and forms of interaction are important. public administration bodies and local self-government bodies with a person and a citizen, public organizations.

Further implementation of the policy of building an e-government system directly depends on the political and legal situation of society, the financial and economic capabilities of the state. These factors can make significant adjustments in the process of e-government, in the pace of reform measures. Along with new developments and advances in the IT field, there is a need to create reliable protection of cyberspace. To reduce the risk of threats, considerable attention should be paid to cybersecurity.

In the perspective research, it is expedient to study the peculiarities of the organization of feedback in the sector "citizen-citizen” of e-government and to identify common difficulties that arise in the interaction of state and citizens in the process of providing public services and public control.

\section{REFERENCES}

Beth Simone Noveck (2011). Wiki Government: How Technology Can Make Government Better, Democracy Stronger, and Citizens More Powerful. Brookings Press. 
Cabinet of Ministers of Ukraine (2011). International initiative "Partnership «Open Government».

Retrieved from https://www.kmu.gov.ua/gromadskosti/gromadyanske-suspilstvo-i-vlada/partnerstvovidkritij-uryad/koordinacijna-rada

Cabinet of Ministers of Ukraine (2017). On approval of the Concept of e-government development in Ukraine. Retrieved from https://zakon.rada.gov.ua/laws/show/649-2017-\%D1\%80\#Text

Council of Europe (2005). Declaration of the Committee of Ministers on human rights and the rule of law in the Information Society. Retrieved from https://www.coe.int/t/dgap/goodgovernance/ Activities/Public participation_internet_governance/Declaration-Information-Society/011_Declaration Final\%20text_en.asp

Horbenko, L. (2017). The subject of law as a category of jurisprudence. (Dissertation for the degree of the candidate of legal sciences). Lviv

Horbenko, 0. (2018). New regulation of cybersecurity in the context of international experience. Lawyer \& Law.21, 15-17. Retrieved from: https://uz.ligazakon.ua/ua/magazine_article/EA011604.

Implementing the President's Agenda for E-Government. E-Government Strategy. Simplified Delivery of Services to Citizens (2002, February). Washington: Office of Management and Budget.

Kononenko, T. (1994). Types of communication as an element of the historical process (socio-philosophical analysis) (Dissertation for sciences degree of the candidate of legal sciences). Kyiv.

Kozyubra, M. (Ed.). (2005). General theory of law: a textbook. Kyiv: Science.

OECD (2013). Draft OECD Principles on Digital Government Strategies: Bringing Governments Closer to Citizens and Businesses/GOV/PGC/EGOV. Retrieved from http://prodstoragehoeringspo .blob.core.windows. net/44ae30ce-bca0-4f4d-87db-4ad733d9c2e1/BILAG\%202\%20-\%20GOV-PGC-GOV(2013)1_draft\%20 OECD\%20Principles\%20on\%20Digital\%20Government \%20S[Текст]trategi.pdf

Petroe, 0. (2012). Social dialogue in public administration: European experience and Ukrainian realities. Kyiv: NADU.

Polyakov, A. (2002). Communicative concept of law (genesis and theoretical and legal justification) (Dissertation for sciences degree of the candidate of legal sciences). Sankt-Peterburg.

Prattipati, S. N. (2003). Adoption of e-governance: Differences between countries in the use of online government services. Journal of American Academy of Business, 3(1/2), 386-391.

Provencher, G. (2013). Droitet communication. Found links. Relaxations on relation between communication and law. Brussels: ME.

Recommendation CM/Rec(2009)1 of the Committee of Ministers to member states on electronic democracy (e-democracy) (Adopted by the Committee of Ministers on 18 February 2009 at the 1049 th meeting of the Ministers' Deputies). Retrieved from https://www.coe.int/t/dgap/goodgovernance/ Activities/Key-Texts/Recommendations/Recommendation_CM_Rec2009_1_en_PDF.pdf

The European Parliament (1999). Directive 1999/93/EC of the European Parliament and of the Council of 13 December 1999 on a Community framework for electronic signatures. Retrieved from https://eur-lex. europa.eu/legal-content/EN/TXT/?uri=CELEX\%3A31999L0093

The National Security and Defense Council has begun to develop a cybersecurity strategy for Ukraine (2020). Retrieved from https://www.ukrinform.ua/rubric-polytics/3105556-u-rnbo-pocali-rozroblatistrategiu-kiberbezpeki-ukraini.html.

The European eGoverment Action Plan 2011-2015 (2011). European Commission. Retrieved from http:// eur-lex.europa.eu/LexUriServ/LexUriServ.do?uri=COM:2010:0743:FIN:EN:PDF.)

Tokarska, A. (2016). Legal communication: theory and its practice. Journal of Eastern European law. 25, 38 - 44.

United Nations (2020). 2020 United Nations E-Government Survey. Retrieved from https://www.un.org/ development/desa/publications/publication/2020-united-nations-e-government-survey

United Nations Commission On International Trade Law (2001). UNCITRAL Model Law on Electronic

Signatures. Retrieved from https://uncitral.un.org/en/texts/ecommerce/modellaw/electronic_signatures

Uphoff, Norman \& Krishna, Anirudh. (2004). Civil society and public sector institutions: More than a zerosum relationship. Public Administration and Development, 24, 357-372. doi.org/10.1002/pad.313

van Hook, Mark (2012). Law as communication (Translation from English: Antonov M., Polyakov A.).

Sankt-Peterburg: Edition House of St. Petersburg State University, LLC «University Publishing Consortium».

Verkhovna Rada of Ukraine (2017). On the Basic Principles of Cyber Security of Ukraine. Law of Ukraine.

Retrieved from https://zakon.rada.gov.ua/laws/show/2163-19\#Text

Verkhovna Rada of Ukraine (1998). On the National Digitalization Program. Law of Ukraine Retrieved from https://zakon.rada.gov.ua/laws/show/74/98-\%D0\%B2\%D1\%80\#Text

von Braun, Joachim (2001). Okinawa Charter on Global Information Society. https://doi.org 10.1007/9783-642-56575-5_40. gal Communication: Towards Comprehensible and Consistent Law.

Yablonsky, V. (2016). Communication of state authorities of Ukraine: challenges and tasks. Implementation of communication of state authorities. 